\title{
The Effect of Emotional Quotient, Academic Loyalty, and Interpersonal Communication on Lecturers' Performance of Mulawarman University Samarinda
}

\author{
Usfandi Haryaka \\ Faculty of Education and Teacher, Mulawarman University, Indonesia \\ usfandiharyaka@ymail.com
}

\begin{abstract}
The objective of this research is to study of effect of emotional quotient, academic loyalty, and interpersonal communication on lecturers' performance of Mulawarman University Samarinda. The data of this research were collected through the use of questionnaire filled out by 130 lecturers chosen randomly by using random sampling technique. The data were obtained by administering questionnaire and analyzed with path analysis. The results of research showed that: (1) emotional quotient positively has significant effect on lecturers' performance, (2) academic loyalty also positively has significant effect on lecturers' performance, (3) interpersonal communication positively has significant effect on lecturers' performance, (4) emotional quotient positively has significant effect on academic loyalty, and (5) emotional quotient positively has significant effect on interpersonal communication.
\end{abstract}

Keywords-performance; emotional quotient; loyalty; interpersonal communication

\section{INTRODUCTION}

Mulawarman University as one of the colleges located in East Kalimantan is responsible for the realization of the national educational objectives. There are still a lot of aspects that need to be improved by the university in order to have an equal position with other leading universities. One of the aspects is related the availability of learning facilities and infrastructure, campus environment management, decent welfare for all lecturers and staffs, and most importantly, sufficient human resources management to support the accomplishment of the national education programs.

Based on the data of October 2011 which were obtained from the Personnel Division, the total number of lecturers working for Mulawarman University was 935 people spreading to 12 faculties, including 583 females and 352 males. Based on the data, it is considered that the quality of educative personnel or lecturers needs to get a special attention and priority. The roles of educative personnel in conducting instructional process, research and community service programs are considerably important elements. The successfulness of higher educational development is determined by the quality of lecturers. The quality of lecturers is closely related to their performance. The lecturer quality itself is demonstrated by the high level of performance.
The result of interview with the Personnel Division of Mulawarman University showed that the lecturers' performance still needs to improve. There were still a limited number of research articles published in accredited journals; there were still a small number of scientific works such as books which were published at the national level and the lecturers still had low interest in participating in the national seminars or other scientific activities.

In terms of teaching and learning practice in the classroom, there were still some aspects which need improvements. These aspects were noticed when an observation was conducted during the action in the Lesson Study. In the reflecting activity, it was found that the lecturers still need to do some improvements in the next meetings in order to make the teaching and learning process run well.

The same problems were also found in the activities related to the accomplishment of community service programs such as providing educational outreaches to the community, which also needs improvements.

In light with the above explanation, it was found that there was a gap between the existing lecturers' performance and the expected lecturers' performance so that it is necessary to have a conducive working atmosphere for the lecturers of Mulawarman University in order to achieve high level of performance.

[1] stated that performance refers to three elements: competence, needs, and environment. Competence and needs or someone's efforts refer to internal factors. The competence and one's efforts are related to one's emotional quotient.

Emotional Quotient is very useful for career development. [2] said that emotional quotient is the determinant factor for the success in career and organization, including decision making, leaderships, technical and strategic breakthroughs, open and honest communications, teamwork and mutual trust relationship, consumer loyalty, as well as creativity and innovations.

Another factor which affects lecturers' performance is academic loyalty. Lecturers' academic loyalty affects lecturers' performance. Loyalty is individual efforts to seriously accomplish their tasks, to give inputs to their efforts and organizations by following the process of self-development in the organizations. [3] stated that loyalty to the organization is 
one component which is related to the commitment to the organization.

[4] proposed that (1) communication with the front workers should be initiated directly by the supervisors. (2) Communication should be in face to face communication and (3) communication should be specific in the local workplace. Therefore, it is necessary to have training on communication competence.

Performance is the quantity and quality that one has achieved in accomplishing particular tasks or jobs under her/his responsibility. A number of factors that can affect lecturers' performance, including (1) self-concept, (2) self-efficacy (3) personality, (4) experience, (5) rewards, (6) working motivation, (7) commitment of the lecturers to improve their own quality, (8) loyalty to the academic environment where they are working, (9) the level of their emotional quotient, (10) interpersonal communication, (11) available facilities and infrastructure, (12) the level of their economy, and so on.

There are some problems found related to the lecturers' performance so that it is necessary to identify them such as follows: (1) the effect of experience on the lecturers' performance, (2) the effect of working motivation on lecturers' performance, (3) the effect of job satisfaction on lecturers' performance, (4) the effect of academic loyalty on lecturers' performance, (5) the effect of interpersonal communication on lecturers' performance, (6) the effect of emotional quotient on academic loyalty, (7) the effect of emotional quotient on interpersonal communication, (8) the effect of experience on interpersonal communication, (9) the effect of emotional quotient on job satisfaction, (10) the effect of emotional quotient on working motivation, (11) the effect of working motivation on lecturers' performance, (12) the effect of rewards on lecturers' performance, (13) the effect of selfconcept on lecturers' performance, (14) the effect of selfefficacy on lecturers' performance, (15) the effect of working duration on lecturers' performance, and (16) the effect of personality on lecturers' performance.

Based on the background and problem identification, the main problem of this study is lecturers' performance. The factors which are considered being influential on lecturers' performance are limited to emotional quotient, academic loyalty, and interpersonal communication

Based on the background, problem identification and limitation as explained above, the problems of this study are formulated as follows:

1. Does Emotional Quotient have direct effect on Lecturers' Performance?

2. Does Academic Loyalty have direct effect on Lecturers' Performance?

3. Does Interpersonal Communication have direct effect on Lecturers' Performance?

4. Does Emotional Quotient have direct effect on Academic Loyalty?

5. Does Emotional Quotient have direct effect on Interpersonal Communication?

\section{THEORETICAL REVIEWS}

\section{A. Performance}

Lecturers' performance is measured based on Law of Republic of Indonesia Number 14 Year 2005 on Teachers and Lecturers which states that competence is a set of knowledge, skills, and behaviors that the teachers or lecturers need to have, master and apply in accomplishing their professional jobs. The competences include pedagogical competence, personality competence, social competence, and professional competence [5].

[6] stated that performance may be defined as the accomplishment of an employee or manager assigned duties and the outcomes produced a job function or activity during spaced time period.

According to the Government Regulation Number 18 Year 2007 on Teacher and Lecturers, pedagogical competence of teachers and lecturers in managing learning in the classrooms includes [5]:

a. Understanding learners' characteristics from different aspects such as social, moral, cultural, emotional and intellectual aspects.

b. Understanding learners' learning styles and difficulties.

c. Facilitating the development of learners' potencies.

d. Mastering learning theories and principles as well as educative learning.

e. Developing curriculum which encourages learners' involvement in learning.

f. Designing educative learning.

g. Implementing educative learning.

h. Understanding learners' family and society background in the context of cultural diversity.

i. Evaluating learning and teaching process.

Professional competence refers to the ability of the teachers or lecturers to master the instructional materials in a broad sense that enables them to guide learners in fulfilling the competence standard. Therefore, teachers and lecturers are expected to have content and practical knowledge related to their fields, to master the structure and materials of the curriculum, to organize the materials of the curriculum and to master and to make use of information and communication technology for learning, as well as to improve the quality of learning through evaluation and research.

Social competence refers to the ability of lecturers to communicate effectively with their students, colleagues, educational staffs, students' parents or guardians, and other people surrounding them. Teachers/Lecturers are expected to [5].

a. Be able to have emphatic and sympathetic communication with their students, students' parents, colleagues, educational staffs and community. 
b. Give contribution to the development of educators in schools and in community, at local, regional, national and global levels.

c. Give contribution to the development of education at local, national and global levels.

d. Make use of information and communication technology to communicate and for self-development.

Personal Competence refers to the possession of good, stable, mature, wise and charismatic personality and the ability to become a model for the learners and community and have good moral.

a. Teachers/Lecturers are expected to be able to:

b. Demonstrate themselves as good, stable, mature, wise and charismatic persons.

c. Demonstrate themselves as persons having good morals and becoming good models for their students and community.

d. Evaluate their own performance (reflective actions).

e. Develop themselves continuously.

Based on Brown's statements which are incorporated with the instructions from Law of Republic of Indonesia Number 14 Year 2005 as well as the Government Regulation Number 18 Year 2007 above, it can be concluded that the indicators that can be used to measure lecturers' performance include pedagogical competence, professional competence, social competence, and personal competence.

Assessment on performance provides a lot of advantages, especially for the organization as a place for groups of people who work together in achieving organizational goals. The results of performance assessment can be used as a consideration in making decision related to personnel matters such as promotion, mutation or dismissal. Performance assessment can also be used to identify the kinds of training and programs required to develop the relevant workers.

Based on the theoretical description above, lecturers' performance in this study can be defined as the ability of lecturers in accomplishing their tasks and their jobs based on the competence and skills they have with the following indicators: pedagogical competence, professional competence, social competence, and personal competence.

\section{B. Emotional Quotient}

Emotional Quotient is the ability possessed by someone in relation to the management of his/her own emotion and the understanding of other's emotion.

[7] stated that the category of emotional quotient includes the situation when people are able to manage their major functions in accomplishing their jobs such as planning, flexible thoughts, and the ability to make adaptation. This statement indicates that emotional quotient refers to one's ability to make good plans, to have flexible thoughts, to make adjustment and adaptation with his/her environment where he or she is living.
[7] places personal intelligence of Gardner into a basic definition of emotional quotient and divides this intelligence into five main regions: (1) emotional self-awareness, (2) emotional self-management, (3) self-motivating, (4) understanding other people's emotion, and (5) establishing interpersonal relationship.

More detailed explanation about emotional quotient is presented as follows. First is emotional self-awareness. It refers to self-awareness of recognizing one's feeling and this becomes the basic emotional quotient. At this stage, monitoring our feelings from time to time is required and this is an important aspect to acquire psychological insights and selfrecognition. The inability in understanding oneself feeling makes someone controlled by his/her feelings, which in turn makes them insensitive to his/her real feelings and this may negatively affect decision making.

Second is emotional self-management. This refers to managing one's feelings to be appropriately expressed. This needs a skill which is dependent on self-awareness. Managing emotion is considered successful when one is able to entertain $\mathrm{him} /$ herself, to release his/her anxiety, sorrows, or irritation as well as any conditions which result from the failure of managing these basic emotions. People who have bad skills in managing their emotions will be continuously fighting against their bad feelings; while those have good skills in managing their emotions will quickly awaken from their life collapse and breakdown.

Third is self-motivating. In self-motivating, managing emotions as an instrument to achieve goals is an important aspect in giving attention, self-motivating and self-controlling and having recreation. The ability to motivate our own self can be demonstrated as follows: (a) having control on our own desires, (b) the degree of anxiety which affects one's performance, (c) the power of positive thinking, (d) optimism, and (e) "flow" condition, that is, a condition when attention is fully devoted to what is happening, meaning that the job or task is focused on only one object. With the ability of selfmotivating, someone will tend to have positive viewpoints in valuing what is happening to him/herself. People who have this kind of ability tend to be more productive and effective in anything they are doing.

Fourth is understanding other people's emotions. Empathy or understanding other people's emotion is developed based on self-awareness. This is also an ability which is dependent on emotional self-awareness, namely a basic "socializing skill". An emphatic person will be able to detect hidden social signals which indicate what other people need and want. On the contrary, those who are not able to make adjustment with their own emotions absolutely will not be able to understand other people's feelings.

Fifth is establishing relationship. The art of developing good relationship is a skill in managing other people's emotions. Establishing relationships is a skill which supports popularity, leadership and interpersonal accomplishment.

Emotional quotient is important not only for our own self but also for other people. [8] mentioned that emotional quotient is the ability to understand our own self and other people, 
including emotional self-awareness, emotional selfmanagement, self-motivating, understanding other people's emotions, and establishing relationships.

Furthermore, emotional quotient is very useful in many important aspects. Robbins argued that emotional quotient is beneficial in motivating someone to involve in important actions in order to survive.

Emotional Quotient is very useful in career development. [2] stated that emotional quotient is a determinant factor to be successful in career and organization, including decision making, leaderships, technical and strategic breakthroughs, open and honest communication, teamwork and mutual trust relationships, consumer loyalty, as well as creativity and innovations.

\begin{tabular}{|l|l|}
\hline Emotional \\
Quotient
\end{tabular}

Fig. 1. The application of emotional quotitent by individuals

[9] states that there are five components of emotional quotient: 1) self-managing, being able to reduce anxiety and desires, appropriately reacting to anger; 2) motivation and willingness to work sincerely, not merely for money or status; (3) empathy; the ability to respond to other people's feelings; 4) self-awareness, being aware of other people's personality; and 5) social competence, namely an ability to establish relationship and to build networking.

[10] considered that emotion is a significant factor that affects performance. He stated that there are five steps of managing emotional quotient: 1) identifying feelings when facing problems; 2) understanding and responding to those feelings; 3) managing emotions; 4) communicating; and 5) applying the relationships of emotional powers.

Therefore, it can be said that emotional quotient can be measured based on its components which include: selfmanaging, motivation, empathy, self-awareness, and the ability to establish social relationships.

Based on the above explanation, it can be concluded that emotional quotient is the capacity of individuals in managing their own emotions and understanding other individuals' emotions, with the following indicators: emotional selfawareness, emotional self-control, self-motivating, showing empathy to other people, and establishing interpersonal relationships.

\section{Loyalty}

Employee loyalty is a condition which involves physical, psychological, and social activities which make individuals willing to observe the applicable rules and to apply them with full responsibility and awareness, as well as to have personal identification towards the efforts to achieve the goals of organization and it is followed by a strong devotion.

Employee Loyalty or devotion is defined as individuals who are working sincerely, contributing to the efforts and goals of organization and following the process of self-development in the organization. [3] stated that organizational loyalty is one of the components which is closely related to the commitment to the organization.

[3] also added that loyalty has something to do with the intention to remain in the organization, but it is not directly related to performance because performance is related to motivation, obvious roles, and workers' competence.

[11] stated that corporate culture education is closely related to employee loyalty and has a significant effect on working achievement. Loyalty consists of the acceptance of values existing in the organization, the ability to fight for the organization, and willingness to remain member of the organization.

[3] define organizational loyalty as: the relative strength on an individual's identification with and involvement in a particular organization. This definition indicates that organizational loyalty means more than merely passive loyalty, but it involves active relationships and employees' intention to give significant contribution to their organization.

The definition of Loyalty as stated above has the following characteristics: (1) the existence of strong beliefs and the acceptance of organizational objectives and values, (2) ready to work hard and (3) strong intention to remain in the organization. These aspects of loyalty can be categorized as affective loyalty because this is related to the extent the individuals feel that their personal goals and values match with the organizational objectives and values. The more congruent between personal and organizational objectives and values, the higher the academic loyalty of the lecturers will be to their institution or organization.

[3] contended that there are two aspects of organizational loyalty. First, organizational loyalty as an attitude refers to the degree in which an employee is able to identify his workplace which is demonstrated by his intention to work and make efforts as good as possible. Second, organizational loyalty as a behavior refers to the process in which an employee makes a firm decision not to leave the organization if he does not make an extremely fatal mistake. [12] states that an employee with high level of loyalty is a more stable and productive employee, thus giving benefits to the organization.

[13] said that there are three components of organizational loyalty, namely affective loyalty, continuant loyalty and normative loyalty.

[14] have similar opinions about loyalty that there are 3 indicators indicating that an employee has loyalty. They are (1) strong trust and acceptance of organizational goals and values, (2) intention to work hard to achieve the organizational goals and (3) strong desire to remain a member of the organization.

Loyalty is not automatically created in the organization but there are certain aspects in the organization which contribute to the realization of employee loyalty. Each aspect is a part of the 
organizational management related to the employee and institution. Steers \& Porter proposed the aspects of loyalty in relation to the attitude which an employee should do and becomes psychological process of creating organizational loyalty. The first is a strong motivation to remain a member of the organization. The power of this aspect is considerably influenced by an individual condition, including needs, goals and compatibility between individuals and the company.

The second is motivation to work hard for the sake of the company. The same perception between employees and the company which is supported by the same goals in the company will create a strong motivation to make maximum efforts.

The third is a firm belief and full acceptance on the organizational values. A firm trust given by an employee is created from the organizational operations which cannot be separated from the trust of the company to the employees to accomplish their jobs. Employee loyalty is created when the employees feel satisfied with the fulfillment of their living needs from their jobs so that they feel secure to work in one company.

From the previous explanations about loyalty, it can be concluded that loyalty is a psychological bound between the employees and the organization which is indicated by trust and acceptance of the organizational goals and values, motivation to work hard to achieve the organizational goals, and willingness to remain the members of the organization.

Based on the theoretical review above, lecturers' academic loyalty is then defined as a psychological bound between the lecturers and the university which is characterized by the following indicators: trust and acceptance of values which are then applied in the institution, motivation to work hard or struggle for the institution, and willingness to remain a member of the institution.

\section{Interpersonal Communication}

Humans have an ability to make contact with others through communication. In life, every creature interacts with another using a variety of means to achieve a certain goal. The problem is whether the interaction is effective or not depends considerably on how the communication is made.

Communication is so important in life community that without communication there will be no interactions in information, ideas, and thoughts that can be delivered to other people, as it is stated by [15]. Without communication, science and its developments will never be able to be delivered and applied as what is expected.

There are some different definitions of communication proposed by communication experts. [16] contends that communication should include the transfer and understanding of message. In light with this opinion, it can be said that someone's idea will not be delivered until it is transferred and understood by other people.

According to [4], interpersonal communication is an interaction that occurs when two people have a dialog or some people have a discussion and every person involving in the dialog or discussion is an active participant.
In relation to the discussion of interpersonal relationship, [17] stated that interpersonal communication is a personal interactive process which is related to delivering and receiving messages both verbally and non-verbally.

The basic goal of interpersonal communication is the delivery of information so that the message sent can be understood by the receiver of the message.

There are many factors that can impede communication and make the message fail to be delivered. Some of the factors include: (a) different interpretations and the meaning of words (semantic factor), (b) different perceptions, (c) bad hearing habits, (d) unclear feedback, and (e) different interpretation of nonverbal communicational.

The definition is supported by [18], who stated that interpersonal communication is face to face communication which enables every participant to handle other people's reactions directly either verbally or non-verbally.

[19] stated that interpersonal communication is a communication between two people who have an obvious relationship. This definition implies that it is almost impossible for communication which occurs between two people or more not regarded as an interpersonal communication. Obviously, there are a variety of relationships, that if they are extended, they may cover small groups and partnerships.

In reality, individuals who involve in interpersonal face to face communication not only use words and grammatical patterns but also use nonverbal gestures and a complex body language to convey meanings. [20] contended that every culture has its own face expressions, action patterns, and gestures whose interpretation standards are different from one to another. This becomes an important dimension in understanding interpersonal communication and becomes a contribution when a message receiver gives feedback.

Communicating is more than merely conversing, speaking and reading. Communication actually occurs when a certain message has been successfully delivered by a group and has been successfully received by another group. Therefore, according to [17], communication can be defined as the transfer of meaningful information among people who are involving in it.

The process of exchanging and understanding information between two or more people is intended to motivate or to influence someone's behaviors. In the process of communication, two important elements are required: a sender and a receiver. The sender is a person who sends an idea or concept to other people and the information may be the expression of thoughts or emotions. The sender is a person who is addressed to receive the message. The sender delivers or encodes the message by selecting symbols used to create message. A message is the real formulation of the idea which is sent to the receiver. The message is sent through a particular channel which becomes a means of communication. A channel can be in the form of official report, telephone conversation, email, or face to face meeting. The receiver decodes the symbols to interpret the meaning of the message. In reality, in delivering and understanding the message these two elements 
usually become the potential source of misunderstanding such as misinterpreting the meaning of symbols of the delivered message. In order to get a response from the delivered message, feedback is required from the receiver of the message.

[21] argued that without feedback, the communication will go one way. Feedback in communication makes the communication run two ways. Feedback is useful to make the communication effective. Feedback enables the sender to ensure whether the receiver is able to correctly interpret the delivered message. In this case, feedback shows how someone can interpret other people's demands on the information they need.

[19] stated that the process of providing effective feedback is characterized by four qualities: (1) freshness, (2) honesty, (3) appropriateness, and (4) clarity.

According to [19], effective communication is affected by (a) positive: high esteem to one self and others, both showing positive attitudes, (b) openness: a high level directness in which self-expression can occur automatically, (c) supportiveness: communication characterized by descriptive comments rather than evaluative ones followed by the acceptance of other people's ideas, (d) equality: a state of not treating people higher or lower than others or not letting other people to treat themselves higher or lower than others. In this case, they should treat others equally and give equal appreciation, (e) empathy: willingness to place their own self into other people's position, trying to understand the difficulties of other people through their own self-perception.

Based on the arguments given by [16, 18, 19, 21] as explained above, it can be concluded that in interpersonal communication there are six indicators of communication, namely: (1) openness; (2) empathy; (3) positive; (4) understanding messages; (5) equality; and (6) feedback.

[22] states that there are four principles in interpersonal communication (1) people always interact and communicate with others, (2) something that has been delivered will be difficult to change, (3) complicated because symbols must be used, that is a language which is understood by both parties, (4) contextual, this can occurs in an isolated space and is always in (a) psychological (b) rational, (c) situational, (d) environmental, (e) cultural contexts.

[22] explained that the functions of interpersonal communication are (1) to spread information, (2) to build a context of understanding, (3) to shape identity, (4) to fulfill interpersonal needs, (5) to establish relations.

The quality of an interpersonal communication is greatly determined by the typical characters of individuals in communicating with other individuals. [21] contended that there are three factors which affect this kind of communication, including (1) self-perception, being aware of one's self in expressing his or her self by (a) capturing the presence of external objects through his or her senses, (b) interpreting the existing information, (2) self-awareness, by understanding his or her own self, (3) Self disclosure, a process of expressing one's self through communication process by giving information about him/herself to other people.
[4] explained that in practice, interpersonal communication is supported by four important factors: (a) technology, (b) intensity of time, (c) differences, and (d) accountability.

Based on theoretical framework above, the meaning of interpersonal communication in this study is the delivery and the acceptance of the message between individuals, both verbally and non-verbally to achieve the predetermined goals with the following indicators: openness, empathy, positive, understanding messages, the same perception and feedback.

\section{THEORETICAL FRAMEWORK}

\section{A. Emotional Quotient and Performance}

Emotional quotient is a component of personality which is connected to someone's psychological factor. Emotional quotient is highly required by everyone, including lecturers for them to make decision suitable with their existing jobs. Someone who has emotional intelligence will have an emotional stability, which in turn will put emphasis on his or her conscience in taking an action or making policy. Lecturers as academic members of the university are required to have emotional intelligence. In communicating with their colleagues, community members and students, lecturers need calmness, both in making decision and in accomplishing their jobs. Therefore they need emotional maturity and stability, which is known as emotional quotient.

Performance is the habit of accomplishing jobs. One who has high performance will always make the time efficient in accomplishing his or her jobs. Time is always an important factor to consider in accomplishing a job. Someone who has a high level of emotional intelligence will be able to handle every problem he/she has. He or she will strive to successfully accomplish his or her tasks as the part of his or her moral responsibility for the jobs.

Some research findings identified that Emotional Quotient plays an important role in the accomplishment of jobs. Emotional Quotient is characterized by the fact that a person has high level of performance [23]. A study conducted to the US Air Force cadets found that the cadets who have high level of performance also show high level of emotional intelligence

[24] conducted a study on school principals' performance, that is, a correlational study between self-concept, empathy, and emotional intelligence and the performance of senior high school principals in South Sumatra. He concluded that there was a positive correlation between self-concept and the school principals' performance; there was a positive correlation between empathy and the school principals' performance, there was a positive correlation between emotional intelligence and the school principals' performance. Based on the above explanation it is assumed that there is a direct effect of emotional quotient on lecturers' performance.

\section{B. Academic Loyalty and Performance}

By having individual attitudes and responsibilities to accomplish academic tasks and to run every program that has been determined by the institution, it means that the individuals have a strong motivation and willingness to implement their 
academic tasks, to make maximum efforts to accomplish their academic jobs, and to make an attempt to participate in developing the university.

The lecturers are demanded to be able to accomplish their instructional tasks and develop their academic competence for the development of the university. If the demand on attitudes and responsibilities can be successfully completed by every lecturer, then their performance will be improved.

[25] states that employee commitment, either high or low, will have an effect on (1) the employee him/herself, for example, self-development of the employee in the organization or company, (2) Organization. Employees with high commitments to the organization will create high organizational performance and reduce the level of absence.

[26] conducted a study on the effect of Rewards, Personality, and Job Satisfaction on the Organizational Commitment of the Teachers of State Vocational High Schools (SMK Negeri) in Bogor. He concluded that personality had a direct effect on the organizational commitment of the teachers of SMK Negeri in Bogor and job satisfaction had a direct effect on organizational commitment of the teachers of SMK Negeri in Bogor, West Java.

Based on the above explanation, it is assumed that there is a direct effect of academic loyalty on the lecturers' performance.

\section{Interpersonal Communication and Performance}

The successfulness in accomplishing tasks is an indicator that someone's performance is influenced by verbal and nonverbal interpersonal communication. Interpersonal interaction will run well if there is a reciprocal relationship between both parties.

Through communication a person or a group will involve directly in one problem they are going to overcome. In overcoming the problem, they need to make efforts and both parties need to make an agreement on how to jointly overcome the problem. Therefore, there will be interdependence and concerns between the party that needs helps and the party that gives help to overcome the problem faced by other people. The higher the intensity of interpersonal communication, the higher the interdependence and concerns both parties will have.

Positive attitude in responding to particular problems and openness in communicating the problem as well as the willingness in accepting suggestion and input from other people will make the interpersonal communication run effectively between two parties.

The improvement of lecturers' performance will be effectively achieved if the lecturers are able to adjust themselves to other people's behaviors and characters and able to anticipate any differences from each individual who interacts in the interpersonal communication. Responsibility for anticipating every problem by giving special concern and direct response will minimize the potential big problems that may arise.

A study conducted by [27] found that Self-Concept Interpersonal Communication, and Self-Efficacy have an effect on Librarians' Performance in the Era of Globalization in the
National Library of Republic of Indonesia. Researcher concluded that Interpersonal Communication and Self-Efficacy have a significant direct effect on Performance. However, Interpersonal Communication is found to have a dominant effect on performance.

Based on the explanation above, it is assumed that there is a direct effect of interpersonal communication on lecturers' performance.

\section{Emotional Quotient and Academic Loyalty}

The indicators that someone has emotional intelligence are that he or she is aware of his or her own emotion, able to control his or her own emotion, and able to motivate his or her own self. This means that an individual who has emotional maturity will have self-confidence. With his or self-confidence, he or she will be able to face any challenge and constraint related to his or her tasks under his or her responsibility. He or she is also able to understand and realize the possibility of success or failure.

Therefore, one who has emotional maturity will have a broad viewpoint about his own self, resilient and optimistic in facing all possibilities, able to motivate his own self to act appropriately in adjusting himself with his working environment.

This is in line with [7] who stated that the category of emotional quotient includes the situation when people are able to manage their major functions in accomplishing their jobs such as planning, flexible thoughts, and the ability to make adaptation. This statement indicates that one's emotional quotient will reflect one's ability to prepare good planning, to have flexible thoughts, to make adjustment and adaptation with his/her environment where he or she is living or working.

A lecturer who has emotional quotient will be able to adjust with the demand as an academic member where he or she is working. Therefore, he or she will have loyalty to the institution.

[2] stated that emotional quotient is a determinant factor for the success in career and organization, including the aspect related to: decision making, leadership, technical and strategic breakthrough, open and honest communication, teamwork and mutual trust relationship, consumer loyalty, as well as creativity and innovations.

This idea especially states that emotional quotient is a determinant factor in consumer loyalty. Based on the explanation above, it is assumed that there is a direct effect of emotional quotient on academic loyalty.

\section{E. Emotional Quotient and Interpersonal Communication}

One of the indicators that someone has emotional maturity is when he or she is able to express empathy to other people and able to establish good relationship with other people. This means that people who have emotional quotient are able to establish good relationship with other people. This also means that they are able to manage other people's emotion. Developing a relationship is a skill which supports popularity, leadership, and interpersonal accomplishment. People who 
successfully possess this skill will also be successful in any field by relying on an efficient and effective communication with others; they are the stars of associated relationships. People who are successful in developing a relationship with others will tend to be extrovert, described as outgoing, cheerful, confident, gregarious, firm, and sociable.

[2] stated that emotional quotient is a determinant factor for the success in career and organization, including the aspects related to: decision making, leaderships, technical and strategic breakthroughs, open and honest communicational, teamwork and mutual trust relationships, consumer loyalty, as well as creativity and innovations. This idea especially implies that emotional quotient is a determinant factor in an open and honest communication, and it affects teamwork and mutual trust relationships. Openness and honesty are two indicators of interpersonal communication. Based on the above explanation, it is assumed that there is a direct effect of emotional quotient on interpersonal communication.

\section{F. Research Hypotheses}

This research hypotheses are (1) there is a direct positive effect of Emotional Quotient on Lecturers' Performance; (2) there is a direct positive effect of Academic Loyalty on Lecturers' Performance; (3) there is a direct positive effect of Interpersonal Communication on Lecturers' Performance; (4) there is a direct positive effect of Emotional Quotient on Academic Loyalty; and (5) there is a direct positive effect of Emotional Quotient on interpersonal Communication.

\section{RESEARCH METHODOLOGY}

The research was conducted at Mulawarman University, Samarinda. The research in the field was conducted for three months, from April 2012 to June 2012 with the following steps: (1) preliminary research, (2) Try-out of the instruments, (3) analysis of the results of try-out instruments, (4) data collection, and (5) data analysis.

The research was designed by using survey method with path analysis approach. The total sample of the research was 130 lecturers taken by using Simple Random Sampling. The data were collected through questionnaire. The research attempted to investigate the relationship among the variables and measure the effect of one variable on another. The research consisted of four variables as follows: Emotional Quotient (X1), Academic Loyalty (X2), Interpersonal Communication (X3), and Lecturers' Performance (Y). The data were analyzed by using path analysis technique. Descriptive analysis was used to display the data, measure central tendency, and to identify the variability of each single variable. Data display was in the form of distribution table and histogram. Central tendency was in the form of mean score, median, modus, minimum and maximum score. The variability was measured by using variance and standard deviation. Inferential analysis was used to test the research hypotheses, applying path analysis which was preceded by testing normality of errors in regression estimation and linearity test. Then, the direct effect of exogenous variables on endogenous variables was calculated. The effect of one variable to another was reflected from its path coefficients.

\section{RESEARCH FINDINGS AND DISCUSSION}

Before doing inferential statistical calculation with path analysis, the requirements for analysis were firstly determined, namely by using normality test of errors and linearity test. The results of which are presented in Table 1 and Table 2 as follows.

TABLE I. SUMMARY OF ERROR NORMALITY TEST

\begin{tabular}{|l|l|l|l|l|}
\hline No & Estimated Errors in Regression & $\mathrm{L}_{\text {table }}$ & $\mathrm{L}_{\text {computed }}$ & Remarks \\
\hline 1 & $\begin{array}{l}\text { Lecturers' Performance on } \\
\text { Emotional Quotient }\end{array}$ & 0,8860 & 0,0551 & Normal \\
\hline 2 & $\begin{array}{l}\text { Lecturers' Performance on Academic } \\
\text { Loyalty }\end{array}$ & 0,8860 & 0,0574 & Normal \\
\hline 3 & $\begin{array}{l}\text { Lecturers Performance on } \\
\text { Interpersonal Communication }\end{array}$ & 0,8860 & 0,0576 & Normal \\
\hline 4 & $\begin{array}{l}\text { Academic Loyalty on Emotional } \\
\text { Quotient }\end{array}$ & 0,8860 & 0,0522 & Normal \\
\hline 5 & $\begin{array}{l}\text { Interpersonal Communication on } \\
\text { Emotional Quotient }\end{array}$ & 0,8860 & 0,0551 & Normal \\
\hline
\end{tabular}

TABLE II. SUMMARY OF REGRESSION LINEARITY TEST

\begin{tabular}{|l|l|l|l|l|}
\hline No & Regression & $F_{\text {computed }}$ & $F_{\text {table }}$ & Remarks \\
\hline 1 & Y on $\mathrm{X}_{1}$ & 1,489 & 1,55 & Linear \\
\hline 2 & $\mathrm{Y}$ on $\mathrm{X}_{2}$ & 1,306 & 1,55 & Linear \\
\hline 3 & $\mathrm{Y}$ on $\mathrm{X}_{3}$ & 1,272 & 1,55 & Linear \\
\hline 4 & $\mathrm{X}_{2}$ on $\mathrm{X}_{1}$ & 1,513 & 1,55 & Linear \\
\hline 5 & $\mathrm{X}_{3}$ on $\mathrm{X}_{1}$ & 1,364 & 1,55 & Linear \\
\hline
\end{tabular}

Furthermore, by applying SPSS, path coefficient can be obtained as it can be seen in Figure 2 as follows.

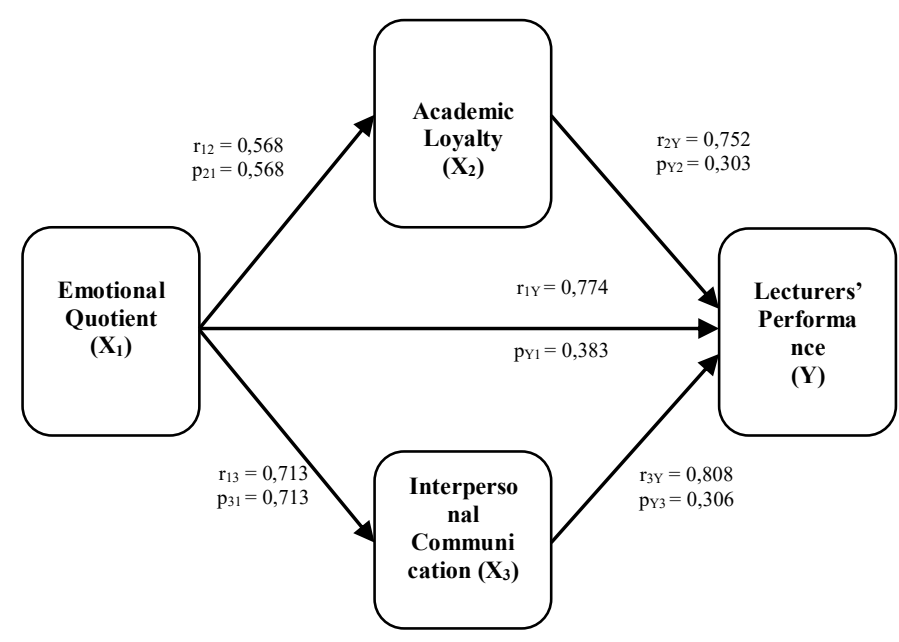

Fig. 2. Diagram model of research variable paths

In summary, the results of hypothesis testing is presented in Table 3 as follows. The result of the first statistical test showed that Emotional Quotient has a direct positive effect on Lecturers' Performance. This finding becomes empirical evidence that Emotional Quotient is important to improve Lecturers' Performance. 
TABLE III. SUMMARY OF THE RESULT OF HYPOTHESIS TESTING

\begin{tabular}{|c|c|c|c|c|}
\hline No & Hypotheses & $\begin{array}{c}\text { Statistical } \\
\text { Test }\end{array}$ & $\begin{array}{c}\text { Decision } \\
\mathbf{H}_{0} \\
\end{array}$ & Conclusion \\
\hline 1 & $\begin{array}{l}\text { Emotional Quotient has a } \\
\text { direct positive effect on } \\
\text { Lecturers' Performance }\end{array}$ & $\begin{array}{l}\mathrm{H}_{0}: \beta_{\mathrm{Y} 1} \leq \\
0 \\
\mathrm{H}_{1}: \beta_{\mathrm{Y} 1}> \\
0\end{array}$ & $\mathrm{H}_{0}$ reject & $\begin{array}{l}\text { Having a } \\
\text { direct positive } \\
\text { effect }\end{array}$ \\
\hline 2 & $\begin{array}{l}\text { Academic Loyalty has a } \\
\text { direct positive effect on } \\
\text { Lecturers' Performance }\end{array}$ & $\begin{array}{l}\mathrm{H}_{0}: \beta_{\mathrm{Y} 2} \leq \\
0 \\
\mathrm{H}_{1}: \beta_{\mathrm{Y} 2}> \\
0\end{array}$ & $\mathrm{H}_{0}$ reject & $\begin{array}{l}\text { Having a } \\
\text { direct positive } \\
\text { effect }\end{array}$ \\
\hline 3 & $\begin{array}{l}\text { Interpersonal } \\
\text { Communication has a } \\
\text { direct positive effect on } \\
\text { Lecturers' Performance }\end{array}$ & $\begin{array}{l}\mathrm{H}_{0}: \beta_{\mathrm{Y} 3} \leq \\
0 \\
\mathrm{H}_{1}: \beta_{\mathrm{Y} 3}> \\
0\end{array}$ & $\mathrm{H}_{0}$ reject & $\begin{array}{l}\text { Having a } \\
\text { direct positive } \\
\text { effect }\end{array}$ \\
\hline 4 & $\begin{array}{l}\text { Emotional Quotient has a } \\
\text { direct positive effect on } \\
\text { Academic Loyalty }\end{array}$ & $\begin{array}{l}\mathrm{H}_{0}: \beta_{21} \leq \\
0 \\
\mathrm{H}_{1}: \beta_{21}> \\
0\end{array}$ & $\mathrm{H}_{0}$ reject & $\begin{array}{l}\text { Having a } \\
\text { direct positive } \\
\text { effect }\end{array}$ \\
\hline 5 & $\begin{array}{l}\text { Emotional Quotient has a } \\
\text { direct positive effect on } \\
\text { Interpersonal } \\
\text { Communication }\end{array}$ & $\begin{array}{l}\mathrm{H}_{0}: \beta_{31} \leq \\
0 \\
\mathrm{H}_{1}: \beta_{31}> \\
0\end{array}$ & $\mathrm{H}_{0}$ reject & $\begin{array}{l}\text { Having a } \\
\text { direct positive } \\
\text { effect }\end{array}$ \\
\hline
\end{tabular}

Emotional Quotient is an individual capacity in managing his/her own emotion and understanding other people's emotions with the following indicators: emotional selfawareness, emotional self-control, self-motivating, empathy to other people, and establishing good relationship with other people. Lecturers who have high level of emotional selfawareness are able to detect their own signs of emotion, able to identify their own feelings, and able to affect their own selves and their own performance. Performance is a habit to do a job. Someone who has high level of performance will always make his or her time efficient to accomplish his or jobs. Time is always an important factor to consider in accomplishing a job. Someone who has an emotional maturity will be able to handle every problem he/she has. He or she will strive to successfully accomplish his or her tasks as the part of his or her moral responsibility for the jobs. Therefore, if the lecturers have high level of emotional intelligence, they will also have a high level of performance.

The previous research findings which support the findings of this research were conducted by the following researchers:

a. The study conducted by [9] concluded that the use of humors by the manager strongly correlated with the competence of emotional intelligence as the key factor for the superior performance of a manager.

b. The study conducted by [24] investigated the correlation between self-concept, empathy, and emotional quotient and the performance of school principals of state high schools in south Sumatera. The data in this study were analyzed by using regression and correlation analysis. [24] concluded that (1) there was a positive correlation between self-concept and the performance of school principals; (2) there was a positive correlation between empathy and the performance of school principals; (3) there was a positive correlation between emotional quotient and the performance of school principals; (4) there was a positive correlation between self-concept, empathy, and emotional quotient and the performance of school principals.

These findings showed that Emotional Quotient has a direct positive effect on lecturers' performance.

The result of the second statistical test showed that Academic Loyalty has a direct positive effect on Lecturers' Performance. This finding empirically proves that academic loyalty is very important in improving lecturers' performance.

Loyalty is a psychological bound of the employees to their organization which is characterized by trust and acceptance of the organization goals and values, strong motivation to strive hard to achieve the organizational goals, and willingness to remain a member of the organization. By the establishment of individual attitudes and responsibility to accomplish academic tasks and to run all of the programs that have been prepared by the institution, it means that the individuals have a strong motivation and willingness to implement their academic tasks, to make maximum efforts to accomplish their academic jobs, and to make an attempt to participate in developing the university. The lecturers are demanded to be able to accomplish their instructional tasks and develop their academic competence for the development of the university. If the demand on attitudes and responsibilities can be successfully completed by every lecturer, then their performance will be improved.

The previous research finding which supports this study includes the study conducted by [25] who concluded that employee loyalty, either high or low, will affect: (1) the employees themselves and (2) organization.

Another study was conducted by [26] who investigated the effect of Rewards, Personality, and Job Satisfaction on the Organizational Commitment of the Teachers of State Vocational High Schools (SMK Negeri) in Bogor. He concluded that personality had a direct effect on the organizational commitment of the teachers of SMK Negeri in Bogor and job satisfaction has a direct effect on organizational commitment of the teachers of SMK Negeri in Bogor, West Java.

[12] were studied also supports the finding of this study. They stated that employees with high level of loyalty are more stable and more productive employees so that they will give more advantages to the organization.

This finding indicates that academic loyalty has a direct positive effect on the lecturers' performance.

The result of the third statistical test showed that Interpersonal Communication has a direct positive effect on Lecturers' Performance. This finding empirically proves that interpersonal communication is important in improving lecturers' performance.

In an organizational life, communication is an inevitable activity in building coordination among the members of the organization. One important type of communication that is required in an organizational life is interpersonal communication, that is, the reciprocal interaction in exchanging meaning between one individual to another, either verbal or non-verbal communication. This kind of communication 
covers the aspects of openness, empathy, positive, understanding messages, the same perception, and feedback. The communication which includes these aspects will create delighted feelings among people involving in the communication. When this condition is applied at workplace for example when employees face problems relevant with their jobs and then they are able to find solutions for the problem then this condition will create satisfaction and spirits to work, which in turn will create working productivity. In other words, when someone has good experiences in many aspects of job in which interpersonal communication is involved, then this will create working productivity or performance.

Communication enables the interactions of information, thoughts, and ideas to be delivered to other people. Therefore, if the process of information delivery and communication with others runs well, it will support the high performance of the lecturers.

The previous research findings which supported the findings of this research include the study conducted by [27] who observed the effect of Self-Concept, Interpersonal Communication, and Self-Efficacy on Librarians' Performance in the Globalization Era at the National Library of Republic of Indonesia. He concluded that Interpersonal Communication and Self Efficacy have a significant direct effect on Performance. However, interpersonal communication is the most dominant factor which affects performance. This is also in line with what Caputo, Hazel, and Baron stated that communication in human life community is important and without communication, science and its development may not be able to be implemented as what is expected. This finding indicates that interpersonal communication has an effect on lecturers' performance.

The result of the fourth statistical test showed that Emotional Quotient has a direct positive effect on Academic Loyalty. This finding shows empirical evidence that Emotional Quotient is very important in improving academic loyalty.

The indicators that people have an emotional quotient include their ability to be aware of their own emotion, to control their own emotion, and to motivate their own selves. This demonstrates that people who have emotional maturity will convince their own selves or will have self-confidence. With this self-confidence, they will assure that they are ready to face any challenge and constraints resulted from their jobs assigned to them. They are also able to understand and to realize the possibility for success or failure. Therefore, someone who has emotional maturity will have a broad view about his own self, resilient and optimistic in facing all possibilities, able to motivate his own self, to act appropriately in adjusting himself with his workplace. This is line with Caruso's view that the category of emotional quotient includes the situation when people are able to manage their major functions in accomplishing their jobs such as planning, flexible thoughts, and the ability to make adaptation. This statement indicates that one's emotional quotient will reflect one's ability to prepare good planning, to have flexible thoughts, to make adjustment and adaptation with his/her environment where he or she is living or working.
A lecturer who has emotional quotient will be able to adjust with any demands related to his/her job as an academic member. Therefore, he or she will have loyalty to the institution.

The findings of the research also support [2] opinion that emotional quotient is a determinant factor for success in career and organization, including: decision making, leaderships, technical and strategic breakthroughs, open and honest communication, teamwork and mutual trust relationships, consumer loyalty and creativity and innovations. The lecturers with a high emotional quotient will also have high academic loyalty.

This finding shows that Emotional Quotient has a direct positive effect on Academic Loyalty.

The result of the fifth statistical test indicates that Emotional Quotient has a direct positive effect on Interpersonal Communication. This finding gives empirical evidence that Emotional Quotient is important in improving Interpersonal Communication.

Emotional quotient is an individual capacity which regulates our own emotions and cares of other people's emotions with the following indicators: being self-aware of our own emotions, being able to control our own emotions, being able to motivate our own selves, having high level of empathy, and being able to establish good communication with others. The indicators that people have emotional maturity include giving empathy to other people and developing good relationship with other people. Therefore, people who have emotional quotient are able to develop good relationship with others, which also means that they have skills in managing other people's emotions. Developing relationship is a skill which supports popularity, leaderships, and interpersonal accomplishment. People who are successful in applying this skill will also be successful in any field by relying on an efficient and effective communication with others; they are the stars of associated relationships. People who are successful in developing a relationship with others will tend to be extrovert, described as outgoing, cheerful, confident, gregarious, firm, and sociable. Interpersonal communication will be effective if the emotional intelligence is in a good condition. Otherwise, communication will not be effective. Therefore, a high Emotional Intelligence will result in a good Interpersonal Communication.

This finding also supports [2] opinion who stated that emotional quotient is a determinant factor for success in career and organization, including: decision making, leaderships, technical and strategic breakthroughs, open and honest communication, teamwork and mutual trust relationship, consumer loyalty and creativity and innovations.

This finding showed that Emotional Quotient has a direct positive effect on Interpersonal Communication

The results of the entire statistical tests showed that emotional quotient, academic loyalty, and interpersonal communication have a direct effect on lecturers' performance. This findings show empirical evidence that emotional quotient, academic loyalty, and interpersonal communication have a direct effect on the lecturers' performance. 
The three variables (Emotional Quotient, Academic Loyalty, and Interpersonal Communication) play important roles in achieving Lecturers' Performance. If one of the three variables is not present, it will make the lecturers' performance become not optimal. To achieve high level of performance, the lecturers are required to be able to apply all of the indicators stated in the Emotional Quotient, namely being aware of their own emotion, being able to control their own emotion, being able to motivate their own selves, having high level of empathy, and being able to establish good communication with others. To achieve high level of performance, they are also demanded to have high academic loyalty by complying with and accepting all of the rules that have been determined by the university, devoting themselves to the university, and struggling to develop it. To achieve a high level of performance the lecturers are required to be able to communicate effectively in their workplace, both to communicate with their colleagues and to the relevant authorities, namely the heads of study programs, the heads of departments, deans, rector, and all of the authorities in the university and able to communicate well with all of the staffs and students as well as the community.

These findings support Griffin's opinion that performance is determined by three factors: ability, willingness, and environment. The result of this research showed that Emotional Quotient, Academic Loyalty, and Interpersonal Communication affect Performance.

\section{CONCLUSION AND RECOMMENDATIONS}

\section{A. Conclusion}

Based on the analysis of research findings it can be concluded as follows.

1. Emotional Quotient has a direct positive effect on lecturers' performance. This means that a high level of Emotional Quotient will result in a high level of Lecturers' Performance.

2. Academic Loyalty has a direct positive effect on lecturers' performance. This means that a high level of Academic Loyalty will result in a high level of Lecturers' Performance.

3. Interpersonal Communication has a direct positive effect on the lecturers' performance. This means a good interpersonal communication will result in a high level of lecturers' performance.

4. Emotional Quotient has a direct positive effect on Academic Loyalty. It means that a high level of Emotional Quotient of the lecturers will result in a high Academic Loyalty.

5. Emotional Quotient has a direct positive effect on Interpersonal Communication. It means that a good Emotional Quotient will result in a good Interpersonal Communication.

\section{B. Recommendations}

Based on the conclusion and implications of the research above, the following points are recommended.
1. Emotional quotient should become a requirement for the recruitment selection of new lecturers in Mulawarman University. By giving emotional quotient test, the university will select new lecturers who have high level of emotional quotient and who are expected to improve their academic loyalty, to establish good interpersonal communication, and to improve their performance.

2. To realize a high level of lectures' academic loyalty, it is expected that every study program, department, and faculty consider doing the following points:

a. Relevant authorities give role models to the lecturers in order to be discipline, honest, reliable, and polite as well as having good behaviors at workplace.

b. Relevant authorities provide control over every action or violation committed by the lecturers but keep creating a conducive atmosphere at workplace and campus environment.

c. Relevant authorities should give appreciation in the form of rewards to the lecturers, who struggle to develop the faculty and university, and to the lecturers who have good working achievement and to those who are retired.

d. Rector and Deans are expected to pay attention to and make efforts to improve the lecturers' welfare in order that all lecturers prefer to stay working and making achievement in their jobs to support the realization of high academic loyalty.

3. It is expected that the authorities at the level of university, faculties, departments and study programs will make attempts to develop high interpersonal communication for the lecturers and staffs in order to create a conducive working relationship and to realize high performance for the lecturers by the following ways.

a. Developing openness character to all of the lecturers and staffs in performing all of the policies.

b. Developing empathic attitude to all of the lecturers and the entire academic community.

c. Developing positive attitudes towards all of the lecturers and academic community.

d. Giving feedback to all aspiration, complaints, and messages proposed by the lecturers.

4. The authorities at university and faculty levels should provide sufficient facilities and infrastructure in campus and should fulfill the needs of all academic community, which finally enable them to make adjustment with the developed universities.

\section{REFERENCES}

[1] R. W. Griffin. (1987). Management.

[2] R. K. Cooper and A. Sawaf. (2001). Executive EQ: Emotional Intelligence in Leadership and Organization. 
[3] R. T. Mowday, L. W. Porter, and R. M. Steers. (1982). Employee Organization Lingkage: The Psychology of Commitment, Absteism \& Turnover.

[4] L. Arrendondo. (2000). Communication Effectively.

[5] Kementerian Pendidikan Nasional, "Undang-Undang RI Nomor 14 Tahun 2005 Tentang Guru dan Dosen," ed, 2005.

[6] R. B. Brown and D. Harvey. (1996). Human Resource Management.

[7] D. R. Caruso and P. Salovey. (2004). Emotionally Intelligent Manager, How to Develop and Use the Four Key Emotional Skill of Leadership.

[8] G. Daniel, B. Richard, and M. Annie. (2005). Primal Leadership: Realizing the Power of Emotional Intelligence.

[9] G. Daniel. (2005). Emotional Intelligence.

[10] G. Lee. (2008). Emotional Intelligence for Managing Results in a Diverse World.

[11] M. Z. A. Rashid, M. Sambasivan, and A. A. Johari, "The Influence of Organizational Culture and Attitude Toward Organization Change," The Leadership \& Organization Development Journal, vol. 25 (2), 2003, 2003.

[12] J. Greenberg and R. A. Baron. (2003). Behavior in Organizations, Understanding and Managing the Human Side of Work.

[13] N. J. Allen and J. P. Meyer, "The Measurement and Antecedents of Affective, Continuance, and Normative Commitment to Organization.," Journal of Occupational Psychology, vol. 63, 1990., 1990.

[14] J. Meyer, P. and N. Allen. (1991). Management at Work.
[15] J. S. Caputo, H. C. Hazel, and C. Mahon. (1994). Interpersonal Communication: Comptency Through Critical Thinking.

[16] S. P. Robbins. (1996). Organization Behavior: Concepts-Controvercies Application.

[17] L. L. Byars and L. W. Rue. (2000). Human Resource Management. Sixth Edition.

[18] D. Mulyana. (2008). Ilmu Komunikasi Suatu Pengantar.

[19] J. A. DeVito. (2011). Komunikasi Antar Manusia. Edisi Kelima.

[20] M. L. DeFleur and E. E. Dennis. (1988). Understanding Mass Communication.

[21] R. L. Daft. (2006). Manajemen. Jilid II.

[22] A. Liliweri. (2004). Wacana Komunikasi Organisasi.

[23] S. P. Robbins and T. A. Judge. (2006). Perilaku Organisasi. Edisi Ke10.

[24] P. Dwi. (2006). Kinerja Kepala Sekolah Studi Korelasional Antara Konsep Diri, Empati dan Kecerdasan Emosional dengan Kinerja.

[25] Sopiah. (2008). Perilaku Organisasional.

[26] Widodo, "Pengaruh Imbalan, Kepribadian, dan Kepuasan Kerja terhadap Komitmen Organisasi Studi Kausal pada Guru SMK Negeri di Kota Bogor Jawa Barat," Jakarta: Program Pascasarjana UNJ, 2009., 2009.

[27] Gardjito, "Pengaruh Konsep Diri, Komunikasi Interpersonal, dan Efikasi Diri terhadap Kinerja Perpustakaan di Era Globalisasi Studi Kausal di Perpustakaan Nasional Republik Indonesia.," Jakarta: Program Pascasarjana Universitas Negeri Jakarta., 2009. 